\title{
Clinical validation of the nursing diagnosis labor pain ${ }^{1}$
}

\author{
Simone Roque Mazoni² \\ Emilia Campos de Carvalho ${ }^{3}$ \\ Cláudia Benedita dos Santos ${ }^{4}$
}

Objective: The study intends to identify the presence of clinical indicators of pain during labor and to correlate the verbal reference of pain intensity with uterine contractions as a proposal to validate the clinical nursing diagnosis Labor Pain. Method: Observational study of the 22 clinical indicators that represented the defining characteristics for the diagnosis. Results: There were 55 participants in labor (18 in the initial active stage, 6 in the final active stage and 31 in both stages), over 18 years old, in their first pregnancy, with effective contractions and cervical dilation of $4 \mathrm{~cm}$ or more. Among the 22 defining characteristics tested, 6 were present in most participants during the two stages: verbal or codified report, noted evidence of uterine contraction, altered muscle tension, noted evidence of pain, expressive behavior and facial expression of pain. There were differences between the stages in relation to perspiration, facial expression of pain, protective gestures, anodyne position, distractive behavior, self-focus and perineum pressure feeling. Conclusions: A positive linear correlation was noted between pain intensity scores and the extent of intra-uterine pressure in the initial stage. Labor pain was proven to be compatible with a nursing diagnosis.

Descriptors: Labor Pain; Pain Measurement; Validation Studies; Nursing Diagnosis.

\footnotetext{
1 Paper extracted from Doctoral Dissertation "Elaboração e validação do diagnóstico de enfermagem Dor de Parto" presented to Escola de Enfermagem de Ribeirão Preto, Universidade de São Paulo, WHO Collaborating Centre for Nursing Research Development, SP, Brazil.

2 Doctoral student, Programa Interunidades de Pós-graduação em Enfermagem, Escola de Enfermagem, Universidade de São Paulo and Escola de Enfermagem de Ribeirão Preto, Universidade de São Paulo, WHO Collaborating Centre for Nursing Research Development, SP, Brazil.

${ }_{3}^{3}$ PhD, Full Professor, Escola de Enfermagem de Ribeirão Preto, Universidade de São Paulo, WHO Collaborating Centre for Nursing Research Development, SP, Brazil.

${ }^{4}$ PhD, Associate Professor, Escola de Enfermagem de Ribeirão Preto, Universidade de São Paulo, WHO Collaborating Centre for Nursing Research Development, SP, Brazil.
} 


\title{
Validação clínica do diagnóstico de enfermagem dor de parto
}

Objetivos: a proposta neste estudo foi identificar a presença dos indicadores clínicos da dor em situação de parto e correlacionar a referência verbal de intensidade de dor com a ocorrência de contrações uterinas, como proposta de validação clínica do diagnóstico de enfermagem dor de parto. Método: trata-se de estudo observacional dos 22 indicadores clínicos que representaram as características definidoras para o diagnóstico. Resultados: participaram 55 parturientes (18 na fase ativa inicial, 6 na fase ativa final e 31 em ambas as fases), maiores de 18 anos, gestação única, contrações efetivas e dilatação cervical $\geq 4 \mathrm{~cm}$. Testaram-se 22 características definidoras, 6 presentes na maioria das participantes nas duas fases: relato verbal ou codificado, evidência observada de contração uterina, alteração do tônus muscular, evidência observada de dor, comportamento expressivo e expressão facial de dor. Houve diferenças entre as fases para diaforese, expressão facial de dor, gestos protetores, posição antálgica, comportamento de distração, foco em si próprio e sensação de pressão perineal. Conclusões: observou-se correlação linear positiva entre escores de intensidade de dor e amplitude de pressão intrauterina na fase inicial. A dor de parto evidenciou-se como fenômeno compatível a um diagnóstico de enfermagem.

Descritores: Dor de Parto; Medição da Dor; Estudos de Validação; Diagnóstico de Enfermagem.

\section{Validación clínica del diagnóstico de enfermería dolor de parto}

\begin{abstract}
Objetivos: El estudio propuso identificar la presencia de los indicadores clínicos de dolor de parto y correlacionar el relato verbal de intensidad del dolor con la ocurrencia de contracciones uterinas, como propuesta de validación clínica del diagnóstico de enfermería Dolor de Parto. Método: Estudio observacional de los 22 indicadores clínicos que representan las características definidoras para el diagnóstico. Resultados: Participaron 55 parturientes (18 en la fase activa inicial, 6 en la fase activa final y 31 en ambas fases), mayores de 18 años, gestación de feto único, contracciones efectivas y dilatación cervical $\geq 4 \mathrm{~cm}$. Fueron testadas 22 características definidoras, 6 presentes en la mayoría de las participantes en las dos fases: relato verbal o codificado, evidencia observada de contracción uterina, alteración del tono muscular, evidencia observada de dolor, comportamiento expresivo y expresión facial de dolor. Fueron encontradas diferencias entre las fases para diaforesis, expresión fácil de dolor, gestos protectores, posición antiálgica, comportamiento de distracción, foco en si mismo y relato de presión perineal. Conclusiones: Se observó correlación linear positiva entre escores de intensidad de dolor y amplitud de presión intrauterina en la fase inicial. El dolor de parto se evidenció un fenómeno compatible para diagnóstico de enfermería.
\end{abstract}

Descriptores: Dolor de Parto; Medición del Dolor; Estudios de Validación; Diagnóstico de Enfermería.

\section{Introduction}

Most women experience labor pain, which is caused by hormonal actions, mechanical and clinical aspects that are part of the natural labor process, as the stimulus that results from events molded by sensorial and emotional experiences, built throughout life $\mathrm{e}^{(1-3)}$.

The most frequent reported location of labor pain is the abdomen, low belly, groin and back ${ }^{(2,4)}$. Labor pain tends to start in the period called latent stage, when contractions are irregular, short in frequency and weak in intensity ${ }^{(5)}$.
During the dilation period, the pain is visceral and results from the uterine contractions and from the cervical dilation, and is transmitted by the fibers located in the sympathetic nervous system. Pain is transmitted to the spinal cord, to the $10^{\text {th }}$ thoracic vertebrae (T10) level and to the $1^{\text {st }}$ lumbar vertebrae (L1) level, resulting in the feeling of pain on the side walls and uterine fundus(5-6). In the second stage, pain is felt in the perineum, anus and rectum and can also be felt in the thighs and legs ${ }^{(2,4-5)}$. 
Hormones are responsible for important actions in the labor process and, consequently, for the pain. The literature describes the nature of the pain related to labor and emphasizes that it results from the pressure caused by uterine contractions, which are instigated by the action of oxytocin. Endogenous endorphins also have a well-known action in this process and act as natural analgesics. Whilst being produced by the mother's system during contractions, they promote a sensation of wellbeing, feelings of satisfaction, selfesteem and safety, and also exert an amnesic effect on pain-related memories, thus reducing the unpleasant sensorial and emotional experiences that are part of the process in this condition ${ }^{(7-8)}$.

Labor pain is part of the nature of human existence and differs from the experiences resulting from sharp and chronic pain. It is not associated with pathology but with life experience(2). Based on the premises that the concept of Labor Pain is different from Sharp Pain, which is present in the NANDA-International Taxonomy ${ }^{(9)}$, given the nature of its occurrence, the clinical indicators that cause labor pain need to be mentioned. It should be reminded that this diagnosis is part of the terminology of the International Classification for Nursing Practice $\operatorname{ICNP}^{\mathrm{tm}(10)}$.

A previous concept analysis has identified the defining characteristics of this event, and also of previous and subsequent events ${ }^{(1,11)}$. These findings have permitted the proposal of a new nursing diagnosis and its submission to the analysis of NANDA International was suggested, for inclusion in Domain 12 - Comfort, Class 1 - Physical Comfort. The points of this proposal are: 1- Diagnosis title: Labor Pain; 2- Definition: Sensorial and emotional experience that varies from pleasant to unpleasant and occurs during labor, resulting from complex interactions among clinical, hormonal and mechanical aspects of labor and from nociceptive stimuli deriving from cervical progress, uterine contractions, cervical dilation and fetal descent, molded by cognitive events of physical, cultural, emotional, psychological origin and sensorial perceptions that vary from low to intense, tending to increase in intensity and frequency from the dilation period to the expelling stage; 3Defining characteristics: noted evidence of uterine contraction, muscle tension alteration, expressive behavior, verbal or codified report, noted evidence of pain, perspiration, facial expression of pain, protective gestures, anodyne position, altered cardiac frequency, altered respiratory frequency, altered blood pressure, altered urinary function, altered endocrine function, distractive behavior, self-focus, pupil dilation, sleep problems, nausea, vomiting, lack of appetite, increased appetite, restricted focus and perineum pressure feeling; 4- Related factors: dilation period: latent stage, active stage, transition stage, expelling stage $\mathrm{e}^{(1,11)}$.

Whilst considering that accurate nursing diagnosis can result in nursing actions directed at the population's actual situation of the population(12), a study about the clinical validity of this diagnosis was undertaken.

The present research was aimed at verifying the frequency of the defining characteristics in relation to the proposed diagnosis of women during the active stage of labor, an also at correlating the verbal report of pain intensity with the occurrence of uterine contractions.

\section{Methods}

The clinical validity of the diagnosis was developed according to the models vastly used in Brazilian studies $^{(13-14)}$. In this observational and prospective study, labor pain was focused on, limited to the observation during the dilation period and the active stage, according to a clinical classification(15) of labor periods. In this perspective, the dilation period is classified into two stages, the latent and the active stages of labor. The active stage, which is the period studied in this research, is revealed by the gradual dilation of the cervix. Initially, the cervix is inconspicuous and, when it achieves three centimeters, the contractions increase and become effective for gradual dilation, their intervals become coordinated and their frequency tends to vary between two and five in a period of 10 minutes, with an average duration of 30 to 45 seconds $^{(8,15)}$.

The research was undertaken at the Pre-Labor Unit of a hospital that is considered a referral institution for high-risk pregnancies, in the countryside of São Paulo state. The people involved in the study were pregnant women admitted to the hospital where the study was undertaken during their active stage of labor. The women in labor with cervix dilation between four and seven centimeters were considered to be in the Initial Active Stage and those with dilation between eight and nine centimeters in the Final Active Stage. Participants who were admitted during the initial active stage and whose labor progressed to eight centimeters of dilation belonged to both groups. The women who progressed to surgical labor with a dilation of less than eight centimeters had their information entered only in relation to the initial active stage; for those admitted with dilation equaling eight centimeters or more, only 
information related to the final active stage was taken into consideration.

The research project was submitted to the Research Ethics Committee of the institution where the study was undertaken, according to CONEP Resolution 196/96, and approved for execution under registration number 34/08.

In view of the limitation of descriptive studies, based on the fact that pain is common during labor and at least $95 \%$ of women in labor present this diagnosis at some time during labor ${ }^{(16)}$, a convenience sample was adopted in a period of approximately two months of observation, considering an average 40 natural labors per month in the institution where this study was undertaken. Therefore, 218 women in labor were admitted in the period from 20 December 2011 to 22 February 2012; from these, 163 were not included in this study, either because they were referred to caesarian birth, were in the expelling stage, presented twin fetuses, had still birth or were under 18 years old.

Women in labor who fit the following requirements were invited to participate in this study: being 18 years of age or older, with gestational age between 28 and 42 weeks or more, not ectopic and single pregnancy, living fetus and longitudinal position, admitted to the Pre-Labor Unit for labor with at least two uterine contractions within ten minutes with a duration of 40 seconds or longer, cervical dilation between 4 and 9 centimeters and thin cervix. The exclusion criteria were established as follows: women in labor who were diagnosed with uterine tear during admission, history of two or more previous caesarians, ultrasound showing extreme prematurity and absolute referral to caesarian section, as well as those women who had been submitted to epidural anesthesia, spinal anesthesia and combined spinal-epidural blockages during the study's assessment or who requested exclusion from the study.

Data collection took place after formal agreement through the signature of two copies of the Informed Consent Form. A document with the socio-graphic and obstetric profile was used, including intervening variables like labor induction, amniotic bag features, amniotic liquid, alternative pain relief techniques, relaxation and fetal descent, and the use of analgesics, as well as variables of interest (that is, the defining characteristics of the proposed diagnosis mentioned above, except for altered urinary function and altered endocrine function, due to the observation time and the characteristics of these clinical indicators). The McGill Pain Questionnaire, translated into Portuguese, was also used, considering the dimension of the sensorial, affective, evaluative and miscellaneous descriptors ${ }^{(17-18)}$ applied for the identification of the indicator Verbal or Codified Report (pain intensity score: 0 to 10 , in which zero means the absence of pain and 10 represents the worst pain intensity) ${ }^{(19)}$ and the pain location for Observed evidence of pain(17-18). In order to identify altered (uterine) muscle tension, the measure of the extent of intrauterine pressure caused by the contractions was considered through the registration of birth monitoring. For this purpose, the fetal cardiac tocogdynamometer was used, brand TOITU tm, MT-516, programmed to register ten minutes.

The clinical environment for data collection included: bed, fetal cardiac tocogdynamometer, data collection instrument for registration of observed clinical indicators, McGill Questionnaire ${ }^{(17-18)}$ (Short Form) and measurement instruments: Visual Analogue Scale for pain $(\text { VAS })^{(19)}$ and a manual Pupilometer ${ }^{(20)}$. The patient was informed about the procedure and asked to stay in the dorsal recumbent position to connect the transducers. The external transducer called Toco, aimed at registering the contractions, was connected at approximately six centimeters below the uterine fundus border in a central position, and the transducer called Cardio was connected to the fetal back or adjacent to it in order to detect the fetal heartbeat and was only used for descriptive purposes. After transducers had been connected, the participants positioned themselves in a left side recumbent position and were oriented to report a pain score after each contraction peak (on a scale from 0 to 10 ). Observations related to the defining characteristics were undertaken from the moment the tocogdynamometer started the registration.

To organize the data, Statistical Package for the Social Sciences (SPSS) software, version 17.0 for Windows was used. Descriptive statistics were used to analyze the study, including the frequency distribution of the nursing diagnosis characteristics under study. Fisher's exact test was used to analyze the differences in the frequencies of the defining characteristics between the initial active stage and the final labor stage. The homogeneity of the samples was evidenced, considering the women in labor who used analgesics or not in both stages in relation to the intervening variables: labor induction, amniotic bag features, amniotic liquid, alternative pain relief techniques, relaxation and fetal descent, and the use of analgesics.

To analyze the co-relation between the variables Extent of Intrauterine Pressure and Verbal or Codified 
Report of Pain, the first measure of the extent of intrauterine pressure in $\mathrm{mmHg}$ registered by the tocogdynamometer and the respective mark given by the women in labor was considered in relation to the pain intensity during the initial and final active stages; Spearman's non-parametric association test was used.

For all statistical tests, significance was set at $\alpha=0.05$.

\section{Results}

From the 55 participants, 31 were women in the initial and final active stages of labor, 18 were only in the initial stage and 6 were in the final active stage. This distribution was based on the labor evolution upon hospital admission and on the medical decision in relation to the labor (surgical or not); therefore, 49 participants were observed in the initial active stage and 37 in the final active stage.

Concerning the participants' characteristics, 34 women $(61.8 \%)$ belonged to the Caucasian ethnic group and 21 (38.2\%) were African descendants, although ethnic mixture is a common feature in Brazil. The age varied between 18 and 38 (mean $=25.3$; Standard Deviation $=5.3$ years). The majority of the women, $48(87.3 \%)$, stated that they had a partner and that their partners lived with them; in relation to the place of residence, 30 (54.5\%) lived in neighboring cities and 25 (45.5\%) lived in the city where the hospital was located.

Also, $42(76.3 \%)$ stated they did not belong to the economically active population and 41 (74.5\%) that they only performed domestic work. As regards their education, this varied between incomplete elementary school and complete secondary school; 19 (31.7\%) completed secondary school and 13 (23.6\%) did not complete elementary school. The approximate minimum family income in reais varied between $R \$ 134.00$ and $\mathrm{R} \$ 4,500.00$ (mean $\mathrm{R} \$ 1,383.80$; Standard Deviation = $\mathrm{R} \$ 841.30)$.

Whilst checking the gestational age through amenorrhea, the majority (67.3\%) were full term pregnancies, that is, from 37 to 41 weeks and 6 days, $14.5 \%$ were pre-term pregnancies, that is, under 37 weeks and two had a gestational age of 42 weeks or longer. Through ultrasound, it was confirmed that most of the gestational ages $(74.5 \%)$ related to full term pregnancies.

From the 22 defining characteristics tested, 17 were in the initial active stage (IAS) and in the final active stage (FAS), but the contraction frequency varied between the two stages. The characteristics altered cardiac frequency and altered respiratory frequency were not observed during the two stages. Other characteristics, such as altered blood pressure, pupil dilation and perineum pressure feeling (the later was observed in most of the participants, that is, 59.5\%), were only noted in the final active stage (Figure 1 ).

Defining characteristics like vomiting, nausea, sleep problems, lack of or increased appetite and restricted focus do not occur often. Although they did not occur often, sleep problems happened in $16.3 \%$ of the cases during the IAS and $35.1 \%$ during the FAS and presented significant statistical differences $(p=0.044)$ (Figure 1$)$.

Six defining characteristics were present in more than $80 \%$ of the participants during the following stages: verbal or codified report (IAS: 100\%; FAS: $100 \%)$, noted evidence of uterine contraction (IAS: 98\%; FAS: $100 \%$ ), altered muscle tension (IAS: 98\%; FAS: $100 \%$ ), noted evidence of pain (IAS: $100 \%$; FAS: 100\%), expressive behavior (IAS: 93.9\%; FAS: 100\%) and facial expression of pain (IAS: $87.8 \%$; FAS: $100 \%$ ). Another characteristic that was present in more than $80 \%$ of the sample only during the final active stage was the anodyne position (89.2\%) (Figure 1).

More than $50 \%$ of clinical evidence was observed during the IAS for anodyne position to relieve the pain (51\%) and during the FAS for perspiration (54.1\%), perineum pressure feeling $(59.5 \%)$, distractive behavior $(59.5 \%)$, protective gestures/defensive behavior (54.1\%) and self-focus (78.4\%) (Figure 1).

Evidence of uterine contraction was noted similarly during the IAS and the FAS of labor ( $p @ 1.000$ ). Only one woman did not have uterine contractions during the IAS of labor. Altered muscle tension was observed in most women in labor during the IAS and in all of them during the FAS ( $p @ 1.000$ ). The expression of pain feelings was noted in $93.9 \%$ of labor pain cases during the initial active stage and $100 \%$ during the final stage $(p=0.256)$. Verbal or codified report and noted evidence of pain were other characteristics evident in $100 \%$ of the participants during both the IAS and the FAS (Figure 1).

Significant statistical differences in the average frequencies of the defining characteristics were observed when comparing the labor stages under evaluation: perspiration $(p=0.001)$ more frequent during the FAS $(54.1 \%)$; facial expression of pain, present in $87.8 \%$ during IAS and $100 \%$ during FAS $(p=0.035)$; protective gestures/defensive behavior ( $p=0.001)$, present in $54 \%$ during the FAS; anodyne position to relieve the pain 
( $p<0.0001)$ more frequent during FAS. Distractive behavior was more frequent during the FAS (59.5\%) ( $p$
$<0.0001)$ and self-focus more frequent during the FAS $(78.4 \%)(p=0.002)$ (Figure 1$)$.

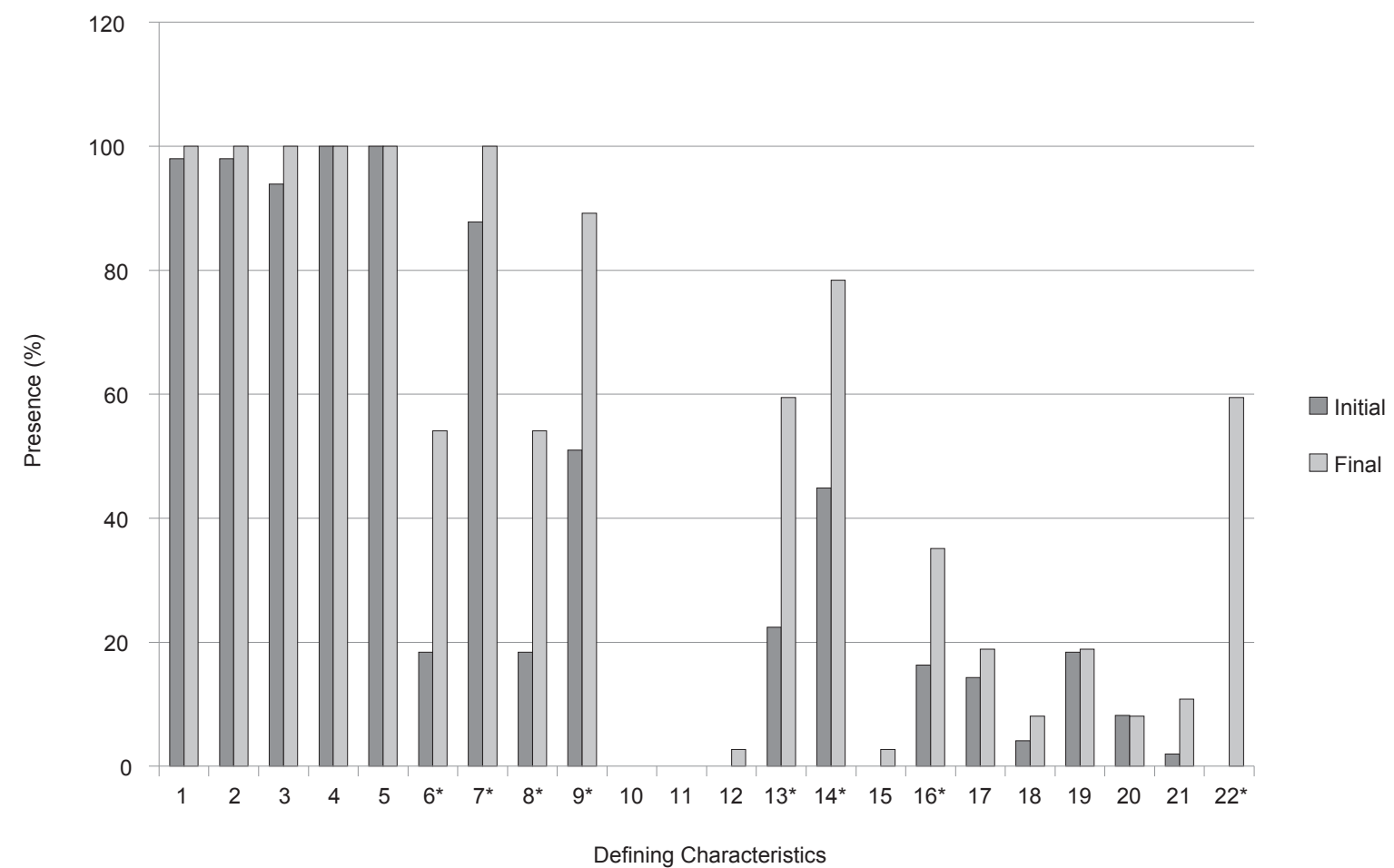

$*_{\mathrm{p}} \leq 0.05 ; 1=$ Noted evidence of uterine contraction; $2=$ Altered muscle tension; $3=$ Expressive behavior; $4=$ Verbal or codified report; $5=$ Noted evidence of pain; $6^{*}=$ Perspiration; $7^{*}=$ Facial expression of pain; $8^{*}=$ Protective gestures $/$ defensive behavior; $9^{*}=$ Anodyne position; $10=$ Altered cardiac frequency; 11 = Altered respiratory frequency; 12 = Altered blood pressure; $13^{*}=$ Distractive behavior; $14 *=$ Self-focus; $15=$ Pupil dilation; $16 *=$ Sleep problems; $17=$ Nausea; $18=$ Vomiting; $19=$ Lack of appetite; $20=$ Increased appetite; $21=$ Restricted focus; $22 *=$ perineum pressure feeling

Figure 1 - Frequency of defining characteristics of labor pain, observed during the initial active stage and the final active stage of labor, Ribeirao Preto, SP, Brazil, 2012

A statistically significant positive linear correlation was identified between pain intensity scores and the extent of intra-uterine pressure in the initial active stage
( $r=0.381 ; p=0.008)$, but no statistically significant linear correlation occurred during the final active stage $(r=0.401 ; p=0.139)$ (Figure 2$)$.
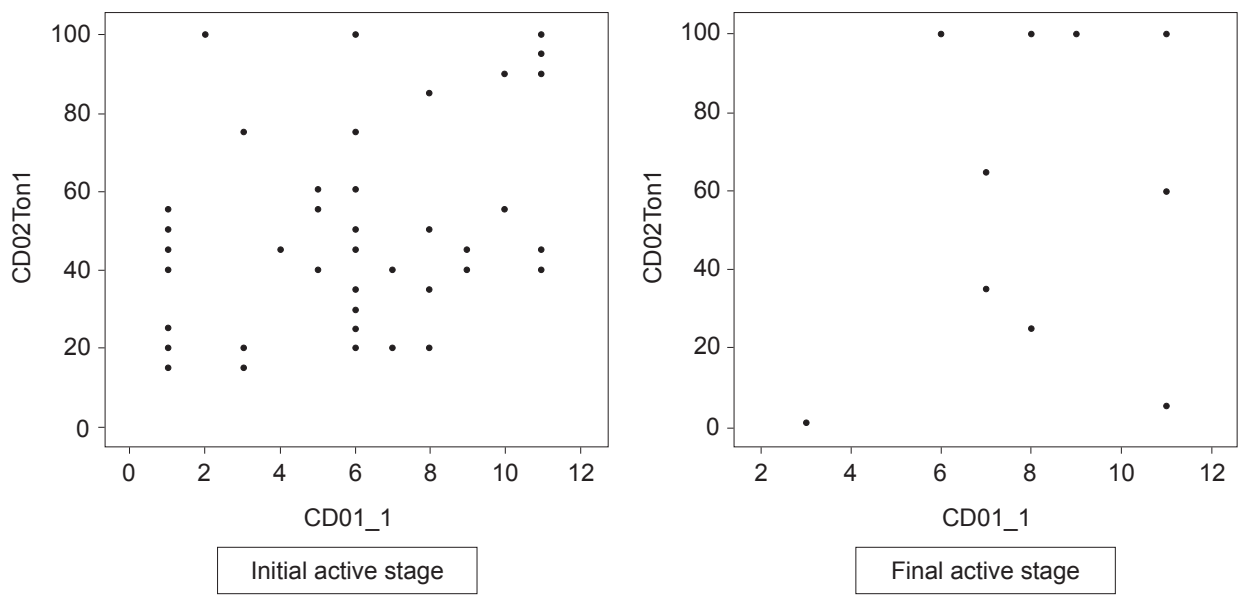

Figure 2 - Dispersion diagram between labor pain intensity scores and the extent of intra-uterine pressure in the initial active stage and in the final active stage, Ribeirao Preto, SP, Brazil, 2012 


\section{Discussion}

The defining characteristics observed within the clinical environment reflected general pain-related indicators, such as: expressive behavior, verbal or codified report, noted evidence of pain, perspiration, facial expression of pain, protective gestures/defensive behavior, anodyne position, distractive behavior, selffocus. clinical indicators peculiar to labor pain were also frequent, such as noted evidence of uterine contraction, altered muscle tension and perineum pressure feeling, the latter of which was evident through reports on the need to evacuate.

Although tangible perception is a subjective evaluation, $80 \%$ of the participants presented moderate intensity contractions. The contractions were also noted through the tocodynagraph of the extent of intrauterine pressure. In relation to the clinical validation, the indicator noted evidence of uterine contraction was present in $98 \%$ during the initial active stage and in all participants during the final active stage.

Another detail is related to altered muscle tension; this presence is not limited to the smooth uterine muscle, which is characterized by the uterine muscle itself, or to the contractions. During the transition period between the active stage and the expelling stage, the muscoloaponeurotic formations tense up and create a muscle belt that compresses the uterus from top to bottom and in the ante posterior direction. At this moment, the altered muscle tension is not localized but diffused to the abdomen ${ }^{(21)}$. In the present study, uterine tension was not analyzed in isolation and, in most cases, it remains stable as the smallest pressure between the contraction peaks; the focus here was on the alteration of the smooth muscle during contractions, which were verified by the extent of the intrauterine pressure through the tocodynagraph of the uterine activity. During the initial active stage, the extent varied between 15 and $100 \mathrm{mmHg}$ and, during the final active stage, the pressure extent varied between 5 and 100 $\mathrm{mmHg}$. In relation to pain, women do not tend to feel contractions from 40 to $50 \mathrm{mmHg}$ during labor. Whilst identifying the extent of intrauterine pressure of 100 $\mathrm{mmHg}$, the presence of effective contractions can be noted, and this pressure, together with the occurrence of about five contractions in a period of 10 minutes at coordinated and repeated intervals, are characteristics of the final active stage ${ }^{(22)}$. The alteration of uterine muscle tension, indirectly measured by the extent of the uterine pressure, was a characteristic the women showed during both active stages of labor (initial and final), being evident in $98 \%$ and $100 \%$, respectively.

Expressive behavior is clearly observed by the emotional reactions of disturbance, moaning, crying, alert, sighing and irritability ${ }^{(9)}$. The feeling of pain during labor can cause tiredness, exhaustion, suffering, stress, tension, loss of control, disturbance, aggressiveness, anger, concern, fear and, at the same time, pleasure ${ }^{(23)}$. This behavior was observed in the women during labor and was present in $93.9 \%$ during the initial active stage and $100 \%$ during the final active stage. Although it was verified that most women expressed this behavior through moaning, sighing and disturbance, a woman having multiple babies at birth expressed herself through a "noisy and genuine laugh" during the contraction periods, which shows that this varies depending on the relevance of pain for the labor event.

In the evaluation of the pain intensity during contractions, during the initial active stage of labor, the women scored between 0 and 10 , but this presented a positive linear correlation with the extent of the uterine pressure according to the Spearman test during the initial active stage, a fact that did not occur during the final active stage. A study ${ }^{(24)}$ that analyzed the correlation between the reported pain intensity scores and the tocodynagraph of 15 participants' uterine activity showed similar results to the present study in relation to the extent of intrauterine pressure in 125 contractions during the dilation period.

Concerning the verbal and codified pain reports verified through the McGill Pain Questionnaire(17-18), the sensorial and affective subclasses were the most mentioned, with pain reported as colic in $87.3 \%$ of cases; a little less than half of the participants in the study used the affective descriptor, stating that the pain is tiresome (49.1\%). Similar results were found in a study that verified the features of pain originating from the same subclasses ${ }^{(3-4)}$.

The pain descriptor "like colic" shows the presence of attributes that define the contractions caused by myometrial physiology, which is formed by smooth muscle cells with gap junctions. When physiological stimulus is conducted through molecular biochemical contraction of the smooth muscle, the action of proteins like actin and myosin, which promote the contraction of the myocyte, as well as the role of oxytocin and other substances like prostaglandins, act towards a contractile activity that determines the ischemia of the myometrial cells ${ }^{(21)}$. It should be emphasized, however, that pain events during labor are complex and subjective(2), and 
are not limited to the contractions, but also include the hormonal, mechanical and clinical physiological aspects that are present during labor and will cause pain molded by physiological, emotional and cognitive aspects, among others; in addition, uterine contractions, despite being the most evident element, do not determine a labor prognosis ${ }^{(21)}$.

The noted evidence of pain was shown by $100 \%$ of the participants, both during the initial and final active stages. Lower abdomen pain was reported by $23.6 \%$ of the participants and is associated with lower back pain in more than $60 \%$ of the reports. The most frequent location of labor pain reported in the literature is the abdomen, lower abdomen, groin and back. During the first stage of labor, pain is limited to the abdomen, lower back and higher sacrum and, during the second stage, it is located in the perineum, anus, rectum and can also be felt around the thigh and leg area(2,4).

Statistical differences were identified $(p<0.05)$ between the frequencies of the defining characteristics perspiration, protective gestures/defensive behavior, anodyne position for pain relief, distractive behavior, self-focus and perineum pressure feeling, when comparing the initial and final active stages, with higher percentage of presence being concentrated in the final active stage. Concerning the pain intensity scores, the participants' marks increase according to the progress of cervical dilation ${ }^{(25)}$.

The perineum pressure feeling, reported as the need to evacuate, was a characteristic found in 59.5\% of the participants in the final active stage, and this was not noted during the initial active stage $(p<0.0001)$. This characteristic was shown to be peculiar to the transitional period from the active stage to the expelling stage, thus confirming the literature ${ }^{(1-4)}$.

Despite methodological variations in relation to the sample and details that distinguish the study design, in one research, great variation in pain intensity was shown by scores 0 to 10 during the contractions throughout the evolution of labor ${ }^{(26)}$. The positive linear correlation between the scores relating to pain intensity and the extent of intrauterine pressure during the initial active stage showed that the pain score increases according to the increase in the contractions, which are evidenced by the extent of intrauterine pressure in $\mathrm{mmHg}$. Therefore, the verbal report of pain intensity, through scores 0 to 10 , was shown to be a variable capable of measuring labor pain in relation to the occurrence of contractions.

The limitations of this study are related to the fact that participants were only observed during the initial active stage, when the dilation and the thinning of the cervix are partial, and during the final active stage, when the Transitional Stage takes place and ends with complete dilation. The defining characteristics Altered urinary function and Altered neuroendocrine function identified in this study were not analyzed either; this exclusion is justified by the unfeasible application of the measures available in the clinical environment during the hospitalization period observed.

\section{Conclusion}

During the clinical validation of the diagnosis Labor Pain proposed herein, differences were observed in the frequency of some variables when considering the initial and final active stages of labor.

The findings confirm the presence of the following clinical indicators or defining characteristics: noted evidence of uterine contraction, altered muscle tension, expressive behavior, verbal or codified report, noted evidence of pain and facial expression of pain as clinical indicators of the nursing diagnosis Labor Pain. Correlations were found between verbal report and noted evidence of uterine contraction, which indicated an association between the increase in pain intensity scores and the increase in intrauterine pressure in $\mathrm{mmHg}$. According to the McGill Pain Questionnaire, the most mentioned pain descriptors are related to the sensorial and affective subclasses, the majority specifying the sensorial descriptor as "colic" which appoints evidence of uterine contraction as a defining characteristic of the diagnosis.

The methods used were satisfactory in the achievement of the objectives. The diagnosis Labor Pain, in our understanding, can be submitted for consideration to NANDA International, Inc.; the methods used confirmed the authors' understanding that labor pain should not be expressed as sharp pain, thus allowing professionals in this field to understand what is observed in clinical practice. The clinical validation of the diagnosis is recommended during other stages of labor though, such as the latent or expelling stages.

\section{References}

1. Mazoni SR, Carvalho EC. Dor de parto: considerações históricas e conceituais. Rev Dor. 2008;9(1):1176-82.

2. Lowe KN. The nature of labor pain. Am J Obstet Gynecol. 2002;186 Suppl 5:16-24.

3. Capogna G, Camorcia M, Stirparo S, Valentini E, Garassini A, Farcomeni A. Multidimensional evaluation 
of pain during early and late labor: a comparison of nulliparous and multiparous women. Int J Obstetric Anesthesia 2010;19:167-70.

4. Dias MD. A mulher e o parto: respostas frente à dor [dissertação de mestrado]. João Pessoa (PB): Universidade Federal da Paraiba; 1996.85 p.

5. Davim RMB, Torres GV, Dantas JC. Efetividade de estratégias não farmacológicas no alívio da dor de parturientes no trabalho de parto. Rev Esc Enferm USP. 2009;43(2):438-45.

6-Fernandes ML, Andrade FCJ. Analgesia de parto: bases anatômicas e fisiológicas. Rev Med Minas Gerais. 2009;19 Supl 3:3-6.

7. Almeida NAM, Soares LJ, Sodré RLR, Medeiros M. A dor do parto na literatura científica da Enfermagem e áreas correlatas indexada entre 1980-2007. Rev Eletr Enferm. 2008;10(4):1114-23. Disponível em: http:// www.fen.ufg.br/revista/v10/n4/v10n4a24.htm

8. Robertson A. El dolor en el parto. ObStare Primavera [periódico na Internet]. 2004 [acesso $20 \mathrm{dez} 2011$ ]; 12:32-9. Disponível em: http://www.obstare.com/ varios/revistas/El\%20Dolor\%20en\%20el\%20Parto.pdf.

9. Herdman, T.H. (Ed.) (2012). NANDA International Nursing Diagnoses: Definitions and Classification, 20122014. San Francisco: Wiley; 2012. p. 478.

10. Conselho Internacional de Enfermeiros. Classificação Internacional para a prática de Enfermagem Versão 2.0.São Paulo: Algol; 2011.

11. Mazoni SR. Elaboração e validação do diagnóstico de enfermagem dor de parto [tese de doutorado]. Ribeirão Preto (SP): Escola de Enfermagem de Ribeirão Preto da Universidade de São Paulo; 2012. 238 p.

12. Silva PO, Gorini MIPC. Validação das características definidoras do diagnóstico de Enfermagem: fadiga no paciente oncológico. Rev. Latino-Am. Enfermagem. [periódico na Internet]; 2012; [acesso 12 ago 2011]; 20(3):[7 telas]. Disponível em: www.eerp.usp.br/rlae 13. Fehring RJ. Methods to validate nursing diagnoses. Heart and Lung. 1987;16(6):625-9.

14. Hoskins LM. Clinical Validation, Methodologies for Nursing Diagnoses Research. In: Carrol Johnson RM, editors. Classification of Nursing Diagnoses: Proceedings of the Eighth Conference; 1989. Philadelphia: Lippincott; 1989. p. 126-31.

15. Greenhill, JP, Friedman EA. Obstetrícia. Rio de Janeiro: Interamericana; 1976.

16. Sociedade Brasileira para Estudo da Dor [Internet]. São Paulo: SBED/IASP; 2007 [acesso 9 set 2012]. Disponível em: http://www.dor.org.br/profissionais/s_ campanhas_mulher.asp
17. Melzack R. The McGill pain questionnaire: major properties and scoring methods. Pain. 1975;1(3):27799.

18. Pimenta CA, Teixeira MJ. Questionário de dor McGill: proposta de adaptação para a língua portuguesa. Rev Esc Enferm USP. 1996;30(3):473-83.

19. McCaffery M, Pasero C. Pain: clinical manual. 2nd ed. St Louis: Mosby; 1999. 795 p.

20. Haines DE. Princípios de neurociência. $2^{\circ}$ ed. Madri: Elsevier Churchill Livingstone; 2003.

21. Montenegro CA, Rezende J Filho. Rezende: obstetrícia fundamental. $12^{\circ}$ ed. Rio de Janeiro: GuanabaraKoogan; 2011. 724 p.

22. Zugaib M. Zugaib obstetrícia. 2 . ed. Barueri: Manole, 2012. p. 324-38.

23. Macedo PO. Significando a dor no parto: expressão feminina da vivência do parto vaginal [dissertação de mestrado na Internet]. Rio de Janeiro (RJ): Faculdade de Enfermagem da Universidade do Estado do Rio de Janeiro; 2007 [acesso 20 mai 2012]. 91p. Disponível em: http://www.dominiopublico.gov.br/pesquisa/ DetalheObraForm.do?select_action $=\&$ co_obra $=89363$

24. Corli O, Grossi E, Roma G, Batagliarin G. Correlation between Subjective Labour Pain and Uterine Contractions: a Clinical Study. Pain. 1986;26:53-60.

25. Mamede FV, Almeida AM, Souza L, Mamede MV. A dor durante o trabalho de parto: efeito da deambulação. Rev. Latino-Am. Enfermagem. [periódico na Internet]. 2007 [acesso 20 maio 2012;15(6):1157-62. Disponível em: http://www.scielo.br/pdf/rlae/v15n6/pt_15.pdf 26. Conell-Prince J, Evans J, Hong D, Shafer S, Flood P. The development and validation of a dynamic model to account for the progress of labor in the assessment of pain. Anesth Anal. 2008;106(5):1509-15. 